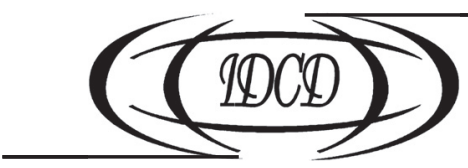

Doi: https://doi.org/10.15407/dse2018.03.148

УДК 331.106:631.1

JEL CLASSIFICATION: J 43

\title{
Є.О. ЛАНЧЕНКО
}

канд. екон. наук, доц., доц. каф. економіки праці та соц. розвитку

Національний університет біоресурсів і природокористування України

03041, м. Київ, вул. Героїв Оборони, 15

E-mail: lanchenko@ukr.net

\section{КОЛЕКТИВНО-ДОГОВІРНЕ РЕГУЛЮВАННЯ СОЦІАЛЬНО- ТРУДОВИХ ВІДНОСИН У АГРАРНОМУ СЕКТОРІ ЕКОНОМІКИ: СТАН І НАПРЯМИ УДОСКОНАЛЕННЯ}

Визначено актуальність досліджень колективно-договірного регулювання соціально-трудових відносин у сільському господарстві в контексті розвитку сільських територій. Виявлено стан виконання нормативних положень Генеральних угод регулювання соціально-трудових відносин на макрорівні. Обгрунтовано концептуальні напрями розвитку соціальної й виробничої сфер у селі для забезпечення продовольчої безпеки країни. Проведено комплексний аналіз укладання й виконання Галузевих угод в аграрному секторі економіки та колективних договорів у сільськогосподарських підприємствах. Визначено необхідність моніторингу системи соціально-трудових відносин у сільському господарстві та формування кадрового потенціалу в агроутвореннях. Запропоновано напрями колективно-договірного регулювання соціально-трудових відносин у сільськогосподарських підприємствах для поліпшення зайнятості сільського населення, підвищення рівня оплати праці найманих працівників і розвитку сільських територій. Обгрунтовано вагоме значення залучення окремого суб'єкта соціально-трудових відносин - представника сільської (селищної, об’єднаної) громади до процесу їх колективно-договірного регулювання у сільськогосподарських підприємствах. Визначено окремий рівень соціально-трудових відносин для узгодження інтересів працівників, роботодавців, державної та місцевої влади, мешканців сільських населених пунктів щодо розвитку сільських територій - укладання колективних угод на рівні громади. Визначено концептуальні заходи регулювання розвитку соціально-трудової сфери в сільському господарстві та їх виконавців на всіх рівнях управління аграрною економікою. Колективно-договірне регулювання відносин у сфері праці є одним із ефективних інструментів соціального партнерства. Тому аграрна й соціальна політика держсави та колективно-договірне регулювання соціально-трудових відносин між працівниками і роботодавиями в сільському господарстві за участі представників сільських (селищних, об’єднаних) громад має забезпечити зайнятість $і$ збільшення доходів сільського населення у контексті соціально-економічного розвитку сільських територій.

Ключові слова: соціально-трудові відносини, аграрний сектор економіки, колективний договір, регулювання, зайнятість, оплата праці. 


\title{
E.А. Ланченко
}

канд. экон. наук, доц., доц. каф. экономики труда и соц. развития

Национальный университет биоресурсов и природопользования Украины

03041, г. Киев, ул. Героев Обороны, 15

E-mail: lanchenko@ukr.net

\section{КОЛЛЕКТИВНО-ДОГОВОРНОЕ РЕГУЛИРОВАНИЕ СОЦИАЛЬНО- ТРУДОВЫХ ОТНОШЕНИЙ В АГРАРНОМ СЕКТОРЕ ЭКОНОМИКИ: СОСТОЯНИЕ И НАПРАВЛЕНИЯ УСОВЕРШЕНСТВОВАНИЯ}

\begin{abstract}
Определена актуальность исследований коллективно-договорного регулирования социально-трудовых отношений в сельском хозяйстве в контексте развития сельских территорий. Выявлено состояние выполнения нормативных положений Генеральных соглашений регулирования этих отношений на макроуровне. Обоснованы концептуальные направления развития социальной и производственной сфер в селе для обеспечения продовольственной безопасности страны. Проведен комплексный анализ заключения и выполнения отраслевых соглашений в аграрном секторе экономики и коллективных договоров на сельскохозяйственных предприятиях. Определена актуальность мониторинга системы социально-трудовых отношений в сельском хозяйстве и формирования кадрового потенциала в агрообразованиях. Предложены направления коллективно-договорного регулирования социально-трудовых отношений в сельскохозяйственных предприятиях для улучшения занятости сельского населения, повышения уровня оплаты труда наемных работников и развития сельских территорий. Обоснованно большое значение привлечения отдельного субъекта социально-трудовых отношений - представителя сельской (поселковой, объединенной) общины в процесс их коллективно-договорного регулирования в сельскохозяйственных предприятиях. Определен отдельный уровень социально-трудовых отношений для согласования интересов работников, работодателей, государственной, местной власти и жителей сельских населенных пунктов по развитию сельских территорий - заключение коллективных договоров на уровне общины. На основе проведенного исследования определены концептуальные мероприятия регулирования развития социально-трудовой сферы в сельском хозяйстве и их исполнители на всех уровнях управления аграрной экономикой. Коллективно-договорное регулирование отношений в сфере труда - один из эффективных инструментов социального партнерства. Поэтому аграрная и социальная политика государства и коллективно-договорное регулирование социально-трудовых отношений между работниками и работодателями в сельском хозяйстве с участием представителей сельских (поселковых, объединенных) общин должны обеспечить занятость и увеличение доходов сельского населения в контексте социально-экономического развития сельских территорий.
\end{abstract}

Ключевые слова: социально-трудовые отношения, аграрный сектор экономики, коллективный договор, регулирование, занятость, оплата труда.

Y.O. Lanchenko

PhD (Economics), Associate Prof.

National University of Life and Environmental Sciences of Ukraine

15, Heroyiv Oborony st., Kyiv, 03041, Ukraine

E-mail: lanchenko@ukr.net

\section{COLLECTIVE-CONTRACTING REGULATION OF SOCIAL AND LABOR RELATIONS IN AGRICULTURE: STATUS AND DIRECTIONS OF IMPROVEMENT}

The relevance of conducting research on collective and contractual regulation of social and labor relations in agriculture in the context of development of rural territories is determined. The conceptual directions of the development of social and industrial spheres in the village for ensuring food safety of the country are grounded. A comprehensive analysis of the conclusion and execution of sectoral contracts in the agricultural and collective contracts at agricultural enterprises is carried out. The necessity of monitoring the system of social and labor relations in agriculture and formation of personnel potential in agribusiness is determined. Ways of collectivecontractual regulation of social and labor relations in agricultural enterprises for the improvement of employment of rural population, increase of the level of pay of labor and development of rural territories, are proposed. The critical importance of attracting an individual subject of industrial relations - a representative of the village (town, united) community in the process of collective bargaining regulation of agricultural enterprises - is proven. A 
separate level of social and labor relations has been determined to harmonize the interests of workers, employers, state and local authorities, rural residents in the development of rural areas - the conclusion of collective agreements at the community level. On the basis of the conducted research the conceptual measures of regulation of development of social and labor sphere in agriculture and their performers at all levels of management of agrarian economy are determined. Collective-contractual regulation of labor relations is one of the effective tools of social partnership. Therefore, the agrarian and social policy of the state and the collective-contractual regulation of social and labor relations between workers and employers in agriculture with the participation of representatives of village (township, united) communities must ensure employment and increase the incomes of rural population in the context of socio-economic development of rural areas.

Keywords: social and labor relations, agricultural, collective contract, regulation, employment, work pay.

Постановка проблеми й актуальність теми. Стан соціально-трудових відносин (надалі - СТВ) у сільському господарстві має вагомий вплив на формування середовища життєдіяльності у селі, оскільки ця галузь залишається там головним «роботодавцем». Рівень життя селян, розвиток сільської соціальної та виробничої інфраструктури, демографічна ситуація істотно залежать від колективно-договірного регулювання СТВ у агропромисловому комплексі (АПК), нормативних положень організації й оплати праці в сільськогосподарських підприємствах, визначення соціальних стандартів і гарантій соціального й пенсійного забезпечення сільського населення тощо.

Важливість дослідження підтверджується формуванням соціально орієнтованої (змішаної) ринкової економіки в багатьох країнах світу, у тому числі і в Україні. Такий процес неможливий без соціального діалогу між сторонами СТВ з метою уникнення соціальних потрясінь. Тому соціальне значення укладання колективних угод і договорів у сфері аграрної праці, формування дієвого механізму їх виконання й контролю підтверджує актуальність аналізування стану колективно-договірного регулювання соціально-трудових відносин у сільському господарстві на макро-, мезо- й мікрорівні та обгрунтування напрямів його поліпшення.

Аналіз останніх досліджень і публікацій. Дослідженню проблем регулювання СТВ присвячено увагу багатьох учених. Зокрема, О.В. Жадан (O.V. Zhadan) акцентує увагу на механізмі державного регулювання СТВ, що забезпечить збереження людського та трудового потенціалів і функціонування соціально орієнтованої ринкової економіки завдяки демократизації СТВ [1]. О.Д. Шемяков (O.D. Shemiakov) стверджує, що процес управління СТВ має забезпечити соціальну безпеку в суспільстві й підвищення якості трудового життя [2]. Через поєднання централізованого й договірного регулювання, як зазначає О.Є. Костюченко (О.Y. Kostiuchenko), стає можливою реалізація балансу інтересів учасників відносин у сфері праці [3].

I.M. Новак (I.M. Novak), дослідивши зарубіжний досвід регулювання СТВ, зазначає, що в сучасних теоріях пріоритетне місце їх регулювання належить інституту «колективних переговорів» [4]. А.М. Колот (А.M. Kolot) стверджує, що договірні методи, які застосовують соціальні партнери, укладаючи угоди і договори на різних рівнях СТВ, є основою функціонування соціального партнерства [5]. В.М. Гончаров (V.M. Honcharov) та інші проаналізували види колективних угод і договорів, економічну складову розвитку державного й договірного регулювання СТВ [6] тощо.

Питанням регулювання СТВ у національній економіці присвячено багато наукових праць, проте на рівні аграрної галузі вони досліджені недостатньо. Так, T.B. Кузькіна (T.V. Kuzkina) і B.I. Шульга (V.I. Shulha) [7, 8] обгрунтували напрями: державного регулювання СТВ і формування організаційно-економічного механізму їх функціонування в сільськогосподарських підприємствах України. У нашому 
дослідженні ми акцентуємо увагу на питаннях розвитку СТВ у аграрному секторі економіки в ракурсі соціально-економічного розвитку сіл і селищ України.

Мета статті: обгрунтувати напрями удосконалення колективно-договірного регулювання СТВ у аграрній сфері АПК.

Завдання дослідження: проаналізувати стан виконання заходів колективних угод і договорів регулювання СТВ у сільському господарстві на всіх рівнях управління економікою; розробити рекомендації колективно-договірного регулювання СТВ в аграрному секторі економіки в контексті розвитку сільських територій.

Новизна. Визначено напрями удосконалення регулювання СТВ у сільському господарстві на державному, обласному, галузевому, громадському рівнях і мікрорівні. Запропоновано розширити кількість сторін колективно-договірного регулювання СТВ у аграрних підприємствах, залучивши до цього представників місцевої влади. Обгрунтовано укладання колективних угод на рівні сільських (селищних, об'єднаної) громад із метою координації зусиль місцевої влади, бізнесу й громадськості для забезпечення гармонійного (паритетного) розвитку підприємництва, соціальної й виробничої сфери та досягнення соціальної злагоди.

Виклад основних результатів дослідження. Кодекс законів про працю України можна вважати загальним «регламентом» СТВ на всіх підприємствах. Правовою основою їх колективно-договірного регулювання є Закон України «Про колективні договори і угоди», яким визначено засади розробки, укладання й виконання колективних угод і договорів. В Україні функціонують такі формалізовані рівні колективно-регулювання СТВ: національний (загальнодержавний) рівень, галузевий (міжгалузевий), регіональний (обласний), виробничий (підприємство, організація, установа) [9].

Генеральна угода, укладена на 2010-2012 pр., яка була чинною до укладання нової угоди 23.08.2016, установлювала основні принципи й норми реалізації соціальноекономічної політики та трудових відносин у країні, міжгалузеві співвідношення в оплаті праці тощо. У преамбулі угоди зазначено, що сторони в період іiї дії (фактично 09.11.2010-22.08.2016) спрямовуватимуть скоординовані зусилля на забезпечення економічного зростання, прискорення людського розвитку та виконання першочергових завдань у соціально-економічній і трудовій сфері, зокрема підвищення рівня зайнятості населення та стале зростання заробітної плати працівників, досягнення стабільності та злагоди в суспільстві.

Слід відзначити такі конкретні позитивні нормативні положення в передостанній Генеральній угоді й намічені практичні заходи суб'єктів ії укладання, яких не було раніше. Це, наприклад, конкретні показники збільшення зайнятості населення й зменшення безробіття; установлення мінімальної заробітної плати в межах 35-45 \% середньої у країні та ії наближення до верхньої позначки; збільшення частки заробітної плати в операційних витратах реалізованих товарів; збільшення середньої заробітної плати в країні та рівня оплати праці в бюджетній сфері; наближення посадового окладу працівника першого тарифного розряду єдиної тарифної сітки (ETC) до мінімальної заробітної плати; перегляд соціальних стандартів і гарантій (відтворювальний рівень заробітної плати, включення норм і нормативів із забезпечення населення житлом) тощо.

Більшість правових норм попередньої Генеральної угоди лягли в основу чинної Генеральної угоди від 23.08.2016. Є оновлені нормативні позиції, зокрема зроблено акцент на таких заходах: підвищення конкурентоздатності товаровиробників; розвиток внутрішнього ринку; легалізація трудових відносин та збільшення економічної активності населення, скорочення нелегальної (тіньової) зайнятості населення; 
збільшення частки основної заробітної плати в структурі фонду оплати праці до кінця 2016 р. до 62 \%, до кінця 2017 року - до 64 \%, а також пошук резервів збільшення до 2020 р. частки оплати праці у ВВП не нижче 60 \%, а у структурі доходів населення - до $65 \%$; зростання середньомісячної заробітної плати в цілому на рівні, вищому за прогнозний індекс споживчих цін тощо.

Оскільки вже є офіційні статистичні дані по зазначених показниках [10], можна здійснити ретроспективний аналіз стану виконання заходів Генеральних угод у 20102017 pp. Так, у 2010-2013 рр. простежується позитивна тенденція виконання багатьох заходів Генеральної угоди, зокрема збільшуються рівень зайнятості і реальна середня заробітна плата, зменшується рівень безробіття тощо. У цей період за стабільного курсу валют зростають оборот роздрібної торгівлі в країні, ВВП, доходи населення та ын. Однак від 2014 р. закономірності макроекономічного розвитку погіршилися у зв’язку з війною та військово-політичною ситуацією в країні.

В Україні простежуються негативні тенденції соціально-економічного розвитку: зменшується середньооблікова кількість штатних працівників; погіршується співвідношення платників ЕСВ і пенсіонерів; в останні роки мінімальна зарплата є меншою за визначену мінімальну межу, задекларовану в Генеральних угодах; частка основної заробітної плати в структурі фонду оплати праці не перевищує 60 \% тощо.

Можна відмітити, що за аналізований період 2010-2017 рр. погоджені спільні заходи Генеральних угод не виконані суб'єктами СТВ національного рівня України:

1) збільшення рівня зайнятості населення, зменшення рівня безробіття в 2014-2017 рр., зменшення плинності кадрів;

2) підвищення кваліфікації працівників не рідше одного разу на п’ять років;

3) установлення мінімальної заробітної плати у межах 35-45 \% від середньої заробітної плати у країні та наближення iï до верхньої межі;

4) наближення посадового окладу працівника першого тарифного розряду ЄTC до мінімальної заробітної плати та збільшення заробітної плати працівників бюджетної сфери;

5) розробка й узгодження механізму розрахунку мінімального рівня заробітної плати, який забезпечуватиме просте відтворення здатності працівника до праці та утримання непрацездатних членів його сім’ї;

6) не включено до сфери застосування державних соціальних стандартів выдповідні норми і нормативи із забезпечення населення житлом тощо;

7) збільшення частки основної заробітної плати працівників у структурі фонду оплати праці, частки оплати праці у ВВП та у структурі доходів населення тощо.

Порівняно з країнами ЄС (28 країн) Україна має більший рівень зайнятості населення та менший показник рівня безробіття (розраховано за методологією МОП), особливо в період 2010-2013 pр. Проте гостро стоїть проблема зайнятості молоді, надання першого робочого місця після закінчення навчання у закладах вищої освіти тощо.

У Генеральній угоді зовсім не згадано про розвиток СТВ у сільському господарстві, хоча у селі сьогодні простежується дуже критична ситуація із зайнятістю, формуванням доходів, соціальним і пенсійним страхуванням у аграрних формуваннях. І це відбувається на тлі стрімкого розвитку агробізнесу: збільшення валового виробництва й експорту сільського сільськогосподарської продукції, прибутків агрокомпаній. Галузь забезпечує до 20 \% зайнятість населення, до 30 \% ВВП та до $40 \%$ експорту країни.

На державному рівні регулювання СТВ варто врахувати таку невідповідність економічного, соціального й громадсько-політичного векторів розвитку сільського 
господарства. Потрібно забезпечити участь як держави, так і суб’єктів агробізнесу в розвитку соціальної та виробничої інфраструктур села. Необхідно запроваджувати заходи інвестиційної, економічної, соціальної політики задля збільшення кількості найманих працівників і підтримки їхніх доходів, удосконалення механізму їх соціального й пенсійного страхування.

Так, для наповнення внутрішнього ринку продовольства й забезпечення збалансованого харчування народу України, поліпшення раціональної зайнятості сільського населення й збільшення його доходів потрібно спрямувати зусилля сторін СТВ на розвиток (у порядку важливості): скотарства, плодівництва, птахівництва, свинарства й рибництва. За нашими розрахунками, виходячи з трудомісткості господарювання в них, можна забезпечити робочими місцями й відповідним соціальним пакетом понад 1 млн осіб. Цей показник відповідає наявному дефіциту кількості робочих місць: понад 0,5 млн селян є безробітними та до 0,5 млн селян є зайнятими, але працюють нерегулярно й не сплачують відповідні внески в позабюджетні соціальні фонди.

Крім того, збільшення виробництва сільськогосподарської продукції, якої бракує для забезпечення раціонального харчового балансу населення України, призведе до збільшення обсягів виробництва продукції в харчовій і інших галузях економіки. За нашими розрахунками, це забезпечить створення додатково ще 1 млн робочих місць. Так можна досягти синергетичного ефекту соціально-економічного розвитку села й міста, аграрного й індустріального комплексів країни тощо.

СТВ на обласному рівні регулюються регіональними (територіальними) угодами. Огляд [9] засвідчив, що вони мають переважно декларативний зміст, порівняно з іншими рівнями регулювання СТВ. Напрями співробітництва місцевих органів влади, регіональних профспілкових структур і об'єднань роботодавців для поліпшення соціально-трудової сфери не мають конкретних цілей і показників, заходів і механізмів виконання, регулярних звітів сторін СТВ та контролю. Відсутній і публічний механізм моніторингу стану виконання зобов'язань кожної зі сторін.

Тому на обласних рівнях регулювання СТВ у сільському господарстві обласним структурам Профспілки працівників АПК і продовольства потрібно активізувати своє представництво й лобіювання власних інтересів у процесі соціального діалогу перед місцевою владою та обласними організаціями Федерації роботодавців АПК і продовольства. При цьому, звичайно, треба ураховувати демографічні, економічні, соціальні, природно-кліматичні, геополітичні умови. Зокрема, на обласному й районному рівнях необхідно удосконалювати транспортно-логістичні системи обслуговування виробників сільськогосподарської продукції регіону.

Відповідна Галузева угода укладається з урахуванням техніко-технологічних і організаційних особливостей виробництва й умов праці в галузях АПК. Ї̈ правові норми регулюють виробничі відносини й СТВ зайнятості, організацію праці та міжкваліфікаційні співвідношення ії оплати, соціальний захист працівників АПК тощо. У сфері сільськогосподарського виробництва остання така угода укладена між Мінагрополітики України, Федерацією роботодавців АПК та продовольства України та Профспілкою працівників АПК на 2014-2016 рр. [11] зі змінами. Вона $є$ чинною і нині.

Сторони вищезазначеної Галузевої угоди спрямовують спільні зусилля на вирішення питань соціального розвитку сільської місцевості, узгодження інтересів працівників і роботодавців, підвищення рівня зайнятості та сталого зростання заробітної плати працівників, виконання соціальних програм, досягнення стабільності та злагоди у трудових колективах сільськогосподарських підприємств. Актуальним 
буде економічний аналіз виконання намічених на цей період заходів суб’єктами СТВ галузевого рівня в аграрному секторі економіки України.

У динаміці за останні два десятиріччя позитивним явищем укладання Галузевих угод на рівні АПК є деталізація й конкретизація правових норм і практичних заходів поліпшення стану СТВ у АПК. Наприклад, це збільшення мінімального розміру тарифної ставки робітника першого розряду як базовий показник формування тарифної сітки й схеми посадових окладів, у розмірі не нижче $105 \%$ розміру мінімальної заробітної плати (раніше цей показник становив 102 \%). А з 2017 р. цей показник установлено на рівні не менше 115 \% від прожиткового мінімуму для працездатних осіб. Проте згідно зі встановленими гарантіями Галузевої угоди все-таки залишається низьким гарантований рівень оплати аграрної праці порівняно із затвердженими відповідними рівнями оплати праці в інших галузях національної економіки.

Суб’єкти СТВ на рівні АПК домовилися сприяти розширенню сфери застосування праці в сільській місцевості, у тому числі за рахунок розвитку фермерства, сімейного бізнесу, зеленого туризму, малого й середнього бізнесу. Тобто тепер сторони аграрних СТВ галузевого рівня виходять за рамки розвитку сільського господарства й мають сприяти розвитку несільськогосподарських видів малого й середнього бізнесу, оскільки, очевидно, це зменшить соціальну напругу в селі, де відчутний великий дефіцит робочих місць.

Середню заробітну плату в сільському господарстві мають намір збільшити до середньої у економіці, а частку витрат на оплату праці у собівартості продукції довести до 30 \%, забезпечувати житлом громадян, які працюють в аграрному секторі економіки. У сільськогосподарських підприємствах має запроваджуватися механізм захисту інтересів працівників у період масових звільнень (оплачуваний один робочий день на тиждень для пошуку нової роботи за два місяці до звільнення, вихідна допомога у разі досягнення певного стажу роботи тощо).

Проведемо ретроспективний аналіз виконання задекларованих головних соціально-трудових нормативних положень Галузевих угод АПК за досліджуваний період 2010-2017 pр. (табл. 1), узявши не тільки чинну, а й попередню Галузеву угоду.

На низькому рівні залишається показник кількості найманих працівників у суспільному секторі аграрної економіки - менше 600 тис. осіб, тоді як у 2000 р. їх налічувалося 2,8 млн, 2010 р. - понад 800 тис. осіб. Питома вага найманих працівників агроформувань у загальному показнику в економіці становить уже близько $6 \%$. В останні роки у валовому виробництві сільськогосподарської продукції суспільний сектор перевищив 60 \%. Не забезпечується в сільськогосподарських підприємствах формування кадрового потенціалу, про що свідчать показники підвищення кваліфікації працівників і плинності кадрів.

Простежується тенденція збільшення ВВП у сільському господарстві, проте ріст заробітної плати порівняно із цим показником відбувся лише в 2016-2017 pp. Позитивною є тенденція збільшення середньої зарплати в галузі та її наближення до середньої в країні. В останні роки збільшуються обсяг інвестування в галузь та рівень рентабельності виробництва агропродукції. Проте у аналізований період залишилися невиконаними такі намічені спільні заходи Галузевих угод суб'єктами СТВ у сільському господарстві:

1) збільшення зайнятості населення, робочих місць у сільському господарстві та зменшення рівня безробіття у селі;

2) забезпечення регулярного підвищення кваліфікації та навчання керівників і фахівців сільськогосподарських підприємств; 


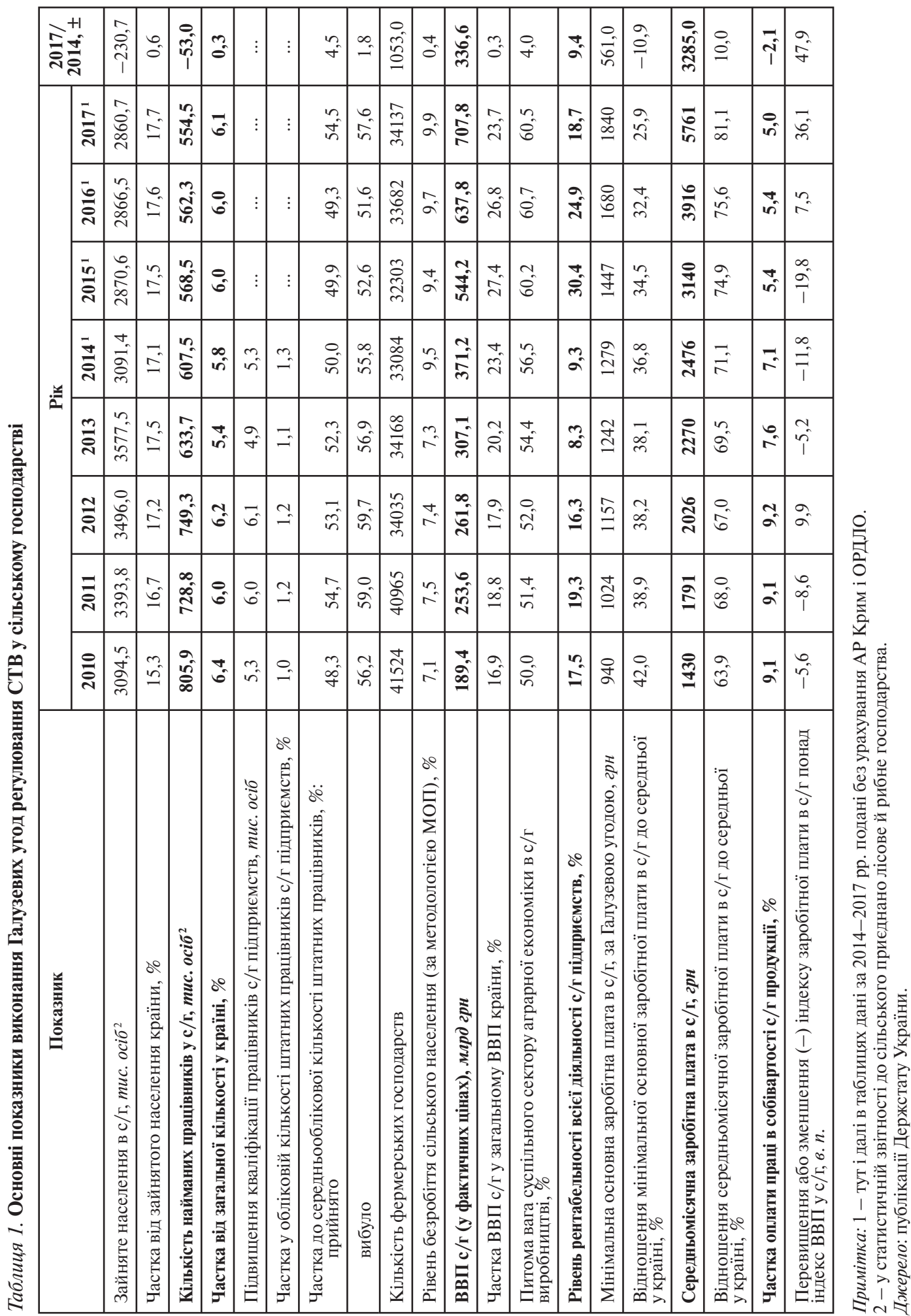


3) збільшення частки оплати праці до 30 \% у структурі собівартості сільськогосподарської продукції;

4) підвищення рівня заробітної плати до середньої у країні та у зв’язку зі щорічним збільшенням ВВП у сільському господарстві;

5) активізація фермерського руху у селі як напрям забезпечення зайнятості селян, збільшення їхніх доходів тощо.

На галузевому рівні регулювання СТВ у сільському господарстві потрібно ретельніше підходити до обгрунтування заходів розвитку аграрної економіки в контексті соціально-економічного розвитку сільських територій. Треба забезпечити постійний і оперативний моніторинг показників соціального, економічного й громадсько-політичного векторів розвитку системи СТВ у сільському господарстві. Він дасть змогу орієнтуватися в паритетності досягнення цілей кожного суб'єкта укладання Галузевої угоди, корегувати та координувати відповідні заходи впливу.

Необхідно забезпечити раціональне землекористування в напрямі підвищення соціальної та екологічної ефективності використання сільськогосподарських угідь, а також збільшення робочої сили в розрахунку на одиницю земельної площі та належний контроль за сівозмінами й родючістю грунтів. Економічний аналіз господарської діяльності в Київській і Чернігівській областях показав, що цього можна досягти шляхом розвитку середньо- й малотоварних форм агробізнесу. Слід спрямовувати більше державної підтримки на розвиток фермерських господарств, сільськогосподарської кооперації, тваринницьких комплексів тощо. Мінагрополітики варто сформувати більше замовлення для аграрних закладів вищої освіти щодо підвищення кваліфікації спеціалістів і фахівців галузі, що забезпечить формування кадрового потенціалу та впровадження інновацій.

Про динаміку укладання колективних трудових договорів на мікрорівні аграрної економіки - у сільськогосподарських підприємствах - можна зробити висновки на основі даних табл. 2.

Кількість укладених колективних трудових договорів у аграрній сфері АПК та кількість працівників, охоплених колективно-договірним регулюванням, має тенденцію до зменшення. Питома вага працівників, які беруть участь в укладанні колективних договорів, у останні роки становить 70-73 \%. Такий рівень показника пояснюється значним зменшенням кількості найманих працівників у аграрних підприємствах протягом досліджуваного періоду та функціонуванням господарств населення, які перебувають поза процесом регулювання аграрних СТВ. У зв'язку із цим у селі гостро постала проблема соціального і пенсійного державного страхування самозайнятих працівників. Крім того, Держстат не подає інформацію про стан укладання договорів у статистично малих підприємствах (до 10 працівників).

Заробітна плата сільськогосподарських працівників майже на 2,4 \% вища на тих підприємствах, де колективний договір діяв. Рівень мінімальної зарплати працівників, затверджений колективними договорами, лише в 1-3\% сільськогосподарських підприємств більший за рівень, установлений Галузевою угодою. У 2017 р. цей показник у промисловості становив $20 \%$, у будівництві - $17 \%$ [10]. Все це свідчить про слабку участь профспілок сільськогосподарських підприємств у переговорному процесі і обгрунтуванні практичних заходів поліпшення СТВ у підприємстві. Статистичні дані свідчать, що в аграрній сфері АПК не зафіксовано жодного страйку, тоді як в промисловості й транспортній сфері це є звичним явищем.

На мікрорівні регулювання аграрних СТВ варто зосередити увагу на удосконаленні структури оплати праці та іiі диференціації по категоріях працівників. Варто 


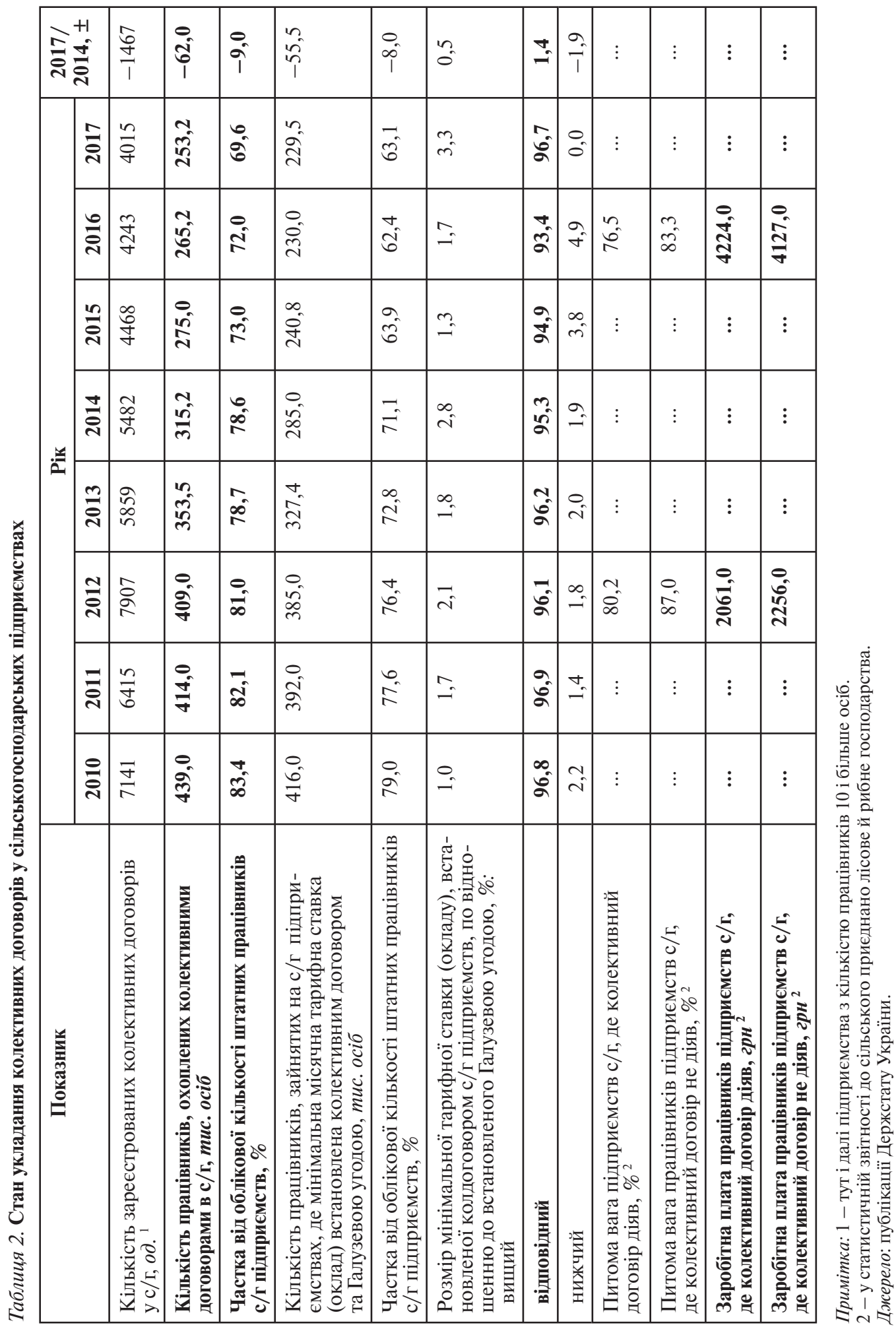


упроваджувати соціальні програми розвитку кадрового потенціалу та заходи підвищення продуктивності праці персоналу підприємства. Плануючи виробництво сільськогосподарської продукції треба намагатись зменшити сезонність використання робочої сили й плинність кадрів, зокрема поєднувати рослинницькі, тваринницькі, переробні й інші виробничі підрозділи тощо.

У зв’язку з тим, що ведення сільськогосподарського виробництва завжди буде торкатись інтересів сільської громади, варто внести зміни в законодавство щодо обов'язкової участі в переговорних процесах з приводу укладання колективних договорів у сільськогосподарських підприємствах представника громади. Це може бути голова (староста) села (селища чи об’єднаної громади) або інша посадова особа, яку уповноважили на засіданні ради депутатів відповідної громади. Таким чином, представник громади захищатиме інтереси сільського населення щодо зайнятості, гідних умов і оплати праці, наповнення місцевого бюджету для фінансування програм соціально-економічного розвитку тощо. Крім того, варто укладати колективні угоди регулювання СТВ на громадському рівні, що забезпечить комплексний розвиток сільських територій України.

Соціальне значення колективно-договірного регулювання СТВ у сільському господарстві полягає в тому, що цей процес забезпечує компроміс інтересів і співробітництво найманих працівників і роботодавців за участю держави, що базується на засадах рівноправності сторін, пріоритетності примирливих методів і процедур, взаємної довіри та регулярності консультацій, обов'язковості виконання досягнутих домовленостей і відповідальності за зобов'язання. Колективні трудові договори можуть укладатися як результат конфронтаційних відносин і бути «мирними угодами» - йдеться про соціальне партнерство, основною метою якого є досягнення спільних найкращих результатів сторонами аграрних СТВ.

Таблиия 3. Напрями колективно-договірного регулювання СТВ у сільському господарстві

\begin{tabular}{|c|c|c|c|}
\hline Рівень СТВ & $\begin{array}{c}\text { Концептуальні напрями } \\
\text { регулювання СТВ }\end{array}$ & Головні виконавці & $\begin{array}{c}\text { Основні джерела } \\
\text { фінансування }\end{array}$ \\
\hline $\begin{array}{l}\text { Національ- } \\
\text { ний }\end{array}$ & $\begin{array}{l}\text { створення робочих місць у ско- } \\
\text { тарстві, плодівництві й інших } \\
\text { трудомістких видах с/г діяль- } \\
\text { ності та харчовій промисловості }\end{array}$ & $\begin{array}{l}\text { уряд; Мінагрополі- } \\
\text { тики; Мінекономіки; } \\
\text { Мінфін }\end{array}$ & $\begin{array}{l}\text { держбюджет; при- } \\
\text { ватні інвестиції }\end{array}$ \\
\hline Обласний & $\begin{array}{l}\text { розвиток інфраструктури аграр- } \\
\text { ного ринку }\end{array}$ & $\begin{array}{l}\text { обл- і райдержад- } \\
\text { міністрації; спілки } \\
\text { роботодавців }\end{array}$ & $\begin{array}{l}\text { держбюджет; міс- } \\
\text { цевий бюджет; при- } \\
\text { ватні інвестиції }\end{array}$ \\
\hline Галузевий & $\begin{array}{l}\text { удосконалення землекористу- } \\
\text { вання; підтримка фермерських } \\
\text { господарств і аграрної освіти; } \\
\text { моніторинг системи аграрних } \\
\text { СТВ }\end{array}$ & $\begin{array}{l}\text { Мінагрополітики; } \\
\text { Міносвіти; НААН; } \\
\text { аграрні ЗВО }\end{array}$ & $\begin{array}{l}\text { держбюджет; місце- } \\
\text { вий бюджет; гранти; } \\
\text { приватні інвестиції }\end{array}$ \\
\hline $\begin{array}{l}\text { Громад- } \\
\text { ський }\end{array}$ & $\begin{array}{l}\text { розвиток соціальної та вироб- } \\
\text { ничої інфраструктур; підтримка } \\
\text { с/г кооперації }\end{array}$ & $\begin{array}{l}\text { муніципальна влада; } \\
\text { підприємства на селі }\end{array}$ & $\begin{array}{l}\text { місцевий бюджет; } \\
\text { гранти; приватні } \\
\text { інвестиції }\end{array}$ \\
\hline $\begin{array}{l}\text { Мікро- } \\
\text { рівень }\end{array}$ & $\begin{array}{l}\text { інновації; удосконалення } \\
\text { мотивації праці та підвищення } \\
\text { іiі продуктивності }\end{array}$ & $\begin{array}{l}\text { с/г підприємства; } \\
\text { профспілки }\end{array}$ & приватні інвестиції \\
\hline
\end{tabular}

Джерело: розробка автора. 
На основі аналізування колективно-договірного регулювання СТВ у сільському господарстві на всіх рівнях управління ми визначили головні напрями й перелік виконавців регулювання аграрних СТВ (табл. 3).

Великий вплив спричинили зміни в демографічній ситуації у селі та міграція робочої сили в інші галузі економіки та за кордон у зв’язку з пошуком кращих умов охорони праці, іiі організації та оплати. Рівень заробітної плати у сільському господарстві протягом більше двох десятиліть залишається найнижчим серед галузей економіки. Тому аграрна й соціальна політика держави та ефективний діалог працівників і роботодавців аграрних формувань, результатом якого є укладання трудового колективного договору, мають забезпечити досягнення соціальної справедливості.

Потрібно мобілізувати всі ресурси та зусилля для підвищення добробуту працівників і сільського населення, забезпечення продовольчої безпеки країни на основі розвитку реального сектора аграрної економіки, підвищення ефективності виробництва сільськогосподарської продукції, розвитку виробничої та соціальної інфраструктури села.

Висновки. Колективно-договірне регулювання відносин у сфері праці є одним із ефективних інструментів соціального партнерства. В укладанні колективних трудових договорів у сільськогосподарських підприємствах не менше за працівників зацікавлені власники підприємств, органи управління сільськими територіями, оскільки нерідко між ними виникають конфліктні ситуації. Тому на макрорівні у ході укладання нової Генеральної угоди на подальші роки слід врахувати особливості «благородної» сільськогосподарської праці й визначити відповідні заходи й виконавців. Необхідно сприяти розширенню сфери зайнятості сільського населення, зокрема в трудомістких підгалузях аграрної економіки, та забезпечити продовольчу безпеку країни.

На галузевому й регіональному рівнях регулювання СТВ відповідним суб'єктам необхідно більше уваги приділяти декларуванню й виконанню заходів збільшення кількості найманих працівників як в аграрних, так і неаграрних видах економічної діяльності у селі. При цьому потрібно враховувати демографічні процеси, регіональну спеціалізацію й концентрацію сільськогосподарського виробництва, забезпечити раціональне використання земельних і трудових ресурсів села. Постає необхідність у оперативному моніторингу паритетності досягнення цілей сторін СТВ у сільському господарстві на галузевому рівні тощо.

У формуванні організаційно-економічного механізму регулювання аграрних СТВ на мікрорівні варто зосередитись на впровадженні організаційних і техніко-технологічних інновацій, поліпшенні мотиваційного механізму персоналу сільськогосподарських підприємств до збільшення продуктивності праці. Показники зайнятості й оплати праці в суспільному секторі аграрної економіки свідчать про послаблення ролі профспілок і недовіру працівників до них. Тому залучення представників громад до колективно-договірного регулювання СТВ у сільськогосподарських підприємствах та укладання колективних угод регулювання СТВ на громадському рівні забезпечить узгодження інтересів «капіталу», «праці» та «громади» у селі.

\section{ЛІТЕРАТУРА}

1. Жадан О.В. Соціально-трудові відносини в умовах глобалізації: теорія та практика державного регулювання. - Харків : С.А.М., 2012. - 360 с.

2. Шемяков О.Д. Розвиток виробничої демократії в управлінні соціально-трудових відносин: теорія і практика. - Донецьк : ВIK, 2012. - 290 с.

3. Костюченко О.С. Державне і договірне регулювання відносин у сфері праці. - Київ : УБС НБУ, 2011. $-187 \mathrm{c}$. 
4. Новак I.М. Удосконалення соціально-економічного механізму регулювання трудових відносин. - Донецьк : ІЕП НАН України, 1998. - 96 с.

5. Колот А.М. Соціально-трудові відносини: теорія і практика регулювання. - Київ : КНЕУ, 2003. $-230 \mathrm{c}$.

6. Механізм державного регулювання соціально-трудових відносин / [В.М. Гончаров, М.В. Рябоконь, А.Є. Пожидаєв і ін.]. - Луганськ : Ноулідж, 2012. - 154 с.

7. Кузькіна Т.В. Розвиток соціально-трудових відносин аграрних підприємств: автореф. дис. ... канд. екон. наук: 08.00.04 «Економіка та управління підприємствами». - Сімферополь, 2009. - 20 c.

8. Шульга B.I. Розвиток соціально-трудових відносин у сільськогосподарських підприємствах: автореф. дис. ... канд. екон. наук: 08.00.04 «Економіка та управління підприємствами». - Київ, 2009. $-20 \mathrm{c}$.

9. Генеральна, Галузеві, Регіональні угоди // Офіційна Інтернет-сторінка Федерації професійних спілок України [Електронний ресурс]. - Режим доступу: http://www.fpsu.org.ua/generalnaugoda-galuzevi-ugodi-teritorialni-ugodi (дата звернення: 01.08.2018).

10. Публікації Держстату України // Офіційна Інтернет-сторінка Держстату України [Електронний pecypc]. - Режим доступу: http://ukrstat.gov.ua (дата звернення: 01.08.2018).

11. Галузеві угоди в АПК // Офіційна Інтернет-сторінка Профспілки працівників АПК України [Електронний ресурс]. - Режим доступу: http://profapk.org.ua/cms/legislature/agreement/ industry/selo.html (дата звернення: 01.08.2018).

\section{REFERENCES}

1. Zhadan, O.V. (2012). Sotsialno-trudovi vidnosyny v umovakh hlobalizatsii: teoriia ta praktyka derzhavnoho rehuliuvannia [Social and labor relations in the conditions of globalization: theory and practice of state regulation]. Kharkiv: S.A.M. [in Ukrainian].

2. Shemiakov, O.D. (2012). Rozvytok vyrobnychoi demokratii v upravlinni sotsialno-trudovykh vidnosyn: teoriia i praktyka [Development of industrial democracy in the management of social and labor relations: theory and practice]. Donetsk: VIK [in Ukrainian].

3. Kostiuchenko, O.Y. (2011). Derzhavne i dohovirne rehuliuvannia vidnosyn u sferi pratsi [State and contractual regulation of labor relations]. Kyiv: UBS NBU [in Ukrainian].

4. Novak, I.M. (1998). Udoskonalennia sotsialno-ekonomichnoho mekhanizmu rehuliuvannia trudovykh vidnosyn [Improvement of the socio-economic mechanism of regulation of labor relations]. Donetsk: IEP NAN Ukrainy [in Ukrainian].

5. Kolot, A.M. (2003). Sotsialno-trudovi vidnosyny: teoriia i praktyka rehuliuvannia [Social and labor relations: the theory and practice of regulation]. Kyiv: KNEU [in Ukrainian].

6. Honcharov, V.M., Riabokon, M.V., \& Pozhydaiev, A.Y., et al. (2012). Mekhanizm derzhavnoho rehuliuvannia sotsialno-trudovykh vidnosyn [The mechanism of state regulation of social and labor relations]. Luhansk: Noulidzh [in Ukrainian].

7. Kuzkina, T.V. (2009). Rozvytok sotsialno-trudovykh vidnosyn ahrarnykh pidpryiemstv [Development of social and labor relations of agricultural enterprises]. Extended abstract of candidate's thesis. Simferopol [in Ukrainian].

8. Shulha, V.I. (2009). Rozvytok sotsialno-trudovykh vidnosyn u silskohospodarskykh pidpryiemstvakh [Development of social and labor relations in agricultural enterprises]. Extended abstract of candidate's thesis. Kyiv [in Ukrainian].

9. Heneralna, Haluzevi, Regionalni uhody [General, branch, regional agreements].fpsu.org.ua. Retrieved from http://www.fpsu.org.ua/generalna-ugoda-galuzevi-ugodi-teritorialni-ugodi [in Ukrainian].

10. Publikatsii Derzhstatu Ukrainy [Publications of the State Statistics Committee of Ukraine]. ukrstat.gov.ua. Retrieved from http://ukrstat.gov.ua [in Ukrainian].

11. Haluzevi uhody v APK [Branch agreements in the agroindustrial complex]. profapk.org.ua. Retrieved from http://profapk.org.ua/cms/legislature/agreement/industry/selo.html [in Ukrainian].

Стаття надійшла до редакції 03.09.2018 